\title{
Investment Cash Flow Sensitivity and Tobin's Q: The Case of Advanced Emerging Markets in Latin America
}

\author{
Bruno Figlioli ${ }^{1}$, Fabiano Guasti Lima ${ }^{1}$ \\ ${ }^{1}$ Accounting Department, School of Economics, Business Administration and Accounting at Ribeirão Preto \\ (FEA-RP), University of São Paulo, Brazil.
}

Correspondence: Bruno Figlioli, (FEA-RP), Av. Bandeirantes, 3900, Monte Alegre, Ribeirão Preto-SP, Brazil.

Received: November 4, 2019

Accepted: December 5, 2019 Online Published: December 10, 2019

doi:10.5539/ibr.v13n1p89

URL: https://doi.org/10.5539/ibr.v13n1p89

\begin{abstract}
This paper examines whether the capital market and the internal generation of cash flows bring relevant information to decisions on corporate investments. For this investigation, we used data from 255 companies located in four Latin American (LA) countries: Brazil, Chile, Mexico and Peru (BCMP countries). The analysis period is from 2000 to 2017. The results indicate that cash flow represents one of the main drivers of corporate investments. In contrast, there were no indications that the capital market translates into a mechanism for transmitting useful information to firm managers about investments. Other drivers of value identified are associated with sales, cash and cash equivalents, and asset tangibility.
\end{abstract}

Keywords: cash flow, corporate investments, Latin America, Tobin's Q

\section{Introduction}

Modigliani and Miller (1958) propose that under perfect market ${ }^{1}$ conditions capital structure is irrelevant to investment decisions. In this perspective of ideal competition and absolute certainty, equity and debt are substitutes, which implies that there is no decision on sources of financing that maximizes a firm's value. The generation of investor wealth therefore focuses on the investment opportunities forming both the expectations of future cash flow generation and their levels of risks.

One theoretical explanation regarding the levels of investment is a finding in Tobin (1969). The question of optimizing investments is derived from the ratio between a firm's market value and the replacement value of its assets. In the Finance literature this ratio is referred to as Tobin's $\mathrm{Q}^{2}$ (hereafter $\mathrm{Q}$ ratio). If the $\mathrm{Q}$ ratio is higher than the unit, the firm can increase its value from new investments.

Considering market imperfections, which are potentially derived from informational asymmetries (Myers \& Majluf, 1984) and agency conflicts (Jensen, 1986; Jensen \& Meckling, 1976), investment levels would be associated with the $\mathrm{Q}$ ratio and ability of firms to generate cash flows internally (Fazzari, Hubbard, \& Petersen, 1988). The restrictions faced by firms in obtaining external funds ${ }^{3}$ would determine the magnitude of the investment-cash flow sensitivity. Thus, higher levels for these types of constraints result in a greater reliance on the internal generation of resources (cash flows) to achieve the investments.

After the pioneering work of Fazzari et al. (1988), many other studies followed with very contrasting results. For example, Kaplan and Zingales (1997), Kadapakkam, Kumar, and Riddick (1998) and Cleary (1999) suggest that firms that have high levels of investment-cash flow sensitivity do not necessarily have restrictions in obtaining external funds. Chen and Chen (2012) provide evidence that the explanatory power of cash flows concerning investments has been declining in the last 40 years in North America. In contrast, Grullon, Hund, and Weston (2018) note that cash flow represents one of the main drivers for investment levels for US firms.

Recently, a line of research has investigated how the development of financial markets verified in several countries relates to the decisions on corporate investments. Moshirian, Nanda, Vadilyev, and Zhang (2017) and Larkin, $\mathrm{Ng}$, and Zhu (2018) indicate that the financial markets of underdeveloped and emerging countries translate into inefficient mechanisms in the generation and transmission of information relevant to the decision-making process. This poor environment of disclosure-relevant information implies a more significant association between investments and cash flow compared to the Q-investment relation. Given the importance of this theme, the present study addresses this issue from the Latin American (LA) scenario. 
LA is characterized as an unstable region for the achievement and maintenance of corporate investments (Diao, Macmillan, \& Rodrik, 2017). The low levels of legal enforcement and property rights in LA mitigate investment and economic growth opportunities (Chong \& López-de-Silanes, 2007). Political risk, institutional strengthening, and corporate governance are sensitive issues for investments in this region (Cuervo-Cazurra, Ciravegna, Megarejo, \& Lopez, 2018; Vianna \& Mollick, 2018). It follows that: i) investors will require additional returns against the higher risk levels in LA compared to more developed economies (Donadelli \& Persha, 2014; Figlioli \& Lima, 2019; Roggi, Giannozzi, \& Baglioni, 2017); and ii) there is a greater caution by economic agents in regard to making long-term investments in LA (Leite, Klotzle, Pinto, \& Silva, 2018). Thus, the determinants of corporate investment in the LA context are still unclear.

Based on the considerations made, the research problem was elaborated according to a conceptual model expanded in relation to the determinants of the investments (it includes both the $\mathrm{Q}$ ratio and the cash flow), being defined as follows: Are the $\mathrm{Q}$ ratio and the internally generated resources (cash flow) relevant drivers for the investments of firms located in LA?

As a way of responding to the research problem, data were collected from companies in four LA countries: Brazil, Chile, Mexico and Peru ${ }^{4}$ (hereafter BCMP). According to Sensoy (2016), these countries (BCMP) represent the largest economies of LA and are classified as "advanced emerging countries". Additionally, they have greater participation both in international trade and regarding foreign direct investments (FDIs) compared to other member countries of LA. Thus, the sample formation considered LA countries with a higher expected level of dynamism about corporate investments. The final sample consisted of information from 255 firms located in BCMP countries. The analysis period is from 2000 to 2017.

To conduct the econometric tests, we used dynamic panel-data models with the generalized method of moments (GMM) estimation, as proposed by Arellano and Bond (1991). According to Agca and Mozumdar (2017), this type of estimator tends to be well specified to test the sensitivity of the relationships between investments, Q ratio, and cash flow. They are also robust estimators even when the econometric models present problems of endogeneity.

The results showed that the company's internal cash flow generation represents one of the main drivers of investments in LA. This result was verified even when considering different specifications for the econometric models and the representative variables of the cash flow.

The evidence of the relationship between corporate investments and cash flow found in the LA context is in line with Larkin et al. (2018), whose findings cover underdeveloped and emerging countries. However, investment-cash flow sensitivity proved to be an inadequate proxy to measure the constraints faced by firms in attracting external resources. Even larger firms with higher levels of cash and cash equivalents, which a priori would be classified as less prone to such restrictions, presented the internal generation of resources as one of the main drivers for their investments. This evidence corroborates the results obtained by Kaplan and Zingales (1997), Kadapakkam, Kumar, and Riddick (1998) and Cleary (1999).

Regarding the Q ratio, no significant results were obtained. Based on Chen, Goldstein, and Jiang (2007); Ascioglu, Hedge, and MacDermott (2008); and Chowdhury, Kumar, and Shome (2016); we tested whether the results obtained for the $\mathrm{Q}$ ratio were associated with the efficiency levels of stock prices to incorporate relevant information. Three different variables were used to capture these levels of efficiency: stock price informativeness $(\psi)$, number of investment analysts and the size of companies. In none of these cases were the results statistically significant for the $\mathrm{Q}$ ratio.

Moreover, the results obtained for the Q-investment relationship were not significant when a series of control variables controlled the tests: sales, cash flow ${ }^{5}$, cash and cash equivalents, company size, financial leverage, asset tangibility, corporate credit ratings, American Depositary Receipts (ADRs) program, property rights for the countries analyzed, crisis periods and investment levels.

Additional tests using the free cash flow to the firm (FCFF) as a dependent variable pointed to the irrelevance of the $\mathrm{Q}$ ratio from this alternative econometric modeling. We also used the estimator developed by Erickson and Whited $(2000,2002,2012)$ to verify whether measurement errors for this variable do not bias the results found for the $\mathrm{Q}$ ratio. No indications of relevance for the $\mathrm{Q}$ ratio were observed.

Overall, the results show that LA capital markets, at least for the study sample, do not provide relevant information for decision making regarding corporate investments. The role of the capital market as a more efficient allocation mechanism, as advocated by Bond, Edmans, and Goldstein (2012), would play a very restrictive role considering the real side of the economy in LA. Other variables related to cash flow, sales, cash 
and cash equivalents, and asset tangibility seem to direct investments in this region. From this, a wide variety of users of economic-financial information, such as investors, creditors, investment analysts, regulators, among others, can benefit from the results achieved to better access the relationships between returns and the expected risks for corporate investments in LA.

The evidence obtained by the present study contributes to the understanding of how the process of corporate investments in less developed countries is carried out, as can be identified in Rosseau and Kim (2008), Moshirian et al. (2017), Larkin et al. (2018), among others, where asset prices tend to reflect their intrinsic value with noise.

The remainder of this work is structured as follows: Section 2 provides a literature review of the dynamics of investments in LA and develops the hypotheses. Section 3 covers the methodological aspects, and Section 4 presents the results and discussion. Section 5 concludes.

\section{Literature Review and Hypotheses Development}

\subsection{Dynamics of Investments in LA}

In the corresponding period from 1990 to 1998, there were higher economic growth rates in LA compared to the previous decade. This growth rate was due to the higher commercial opening of their markets. This strategy has triggered a series of privatizations and increased FDIs. There were also significant increases in the levels of exports and the appreciation of their currencies against the main international currencies, which reduced the cost of importing capital goods. However, this cycle of economic growth was attenuated with the Asian Crisis ${ }^{6}$ (Manuelito \& Jiménez, 2015).

The second cycle of more intense economic growth in LA occurred between 2000 and 2007, known as the "commodities supercycle." During this period, there was a continuous increase in the prices of commodities in the international markets, and with this, a new process of raising exports and FDIs in LA (Manuelito \& Jiménez, 2015). Investments turned sharply to the primary sectors of the economy, which resulted in a sensitive process of deindustrialization in LA countries (Diao et al., 2017). At the governmental level, public policies acted pro-cyclically; that is, they did not aim to mitigate possible economic fluctuations. This aspect would partly explain the political uncertainties of LA (Aguilera, Ciravegna, Cuervo-Cazurra, \& Gonzalez-Perez, 2017).

The "commodities supercycle" ended abruptly at the end of 2007 with the outbreak of the subprime crisis in North America. With the end of this cycle of growth, an increase in inflation rates, worsening debt indicators and instability of currencies were observed for the main LA economies (Brenes, Camacho, Ciravegna, \& Pichardo, 2016). Currently, the recovery of economic growth in LA is relatively low, which is mainly due to the fall in exports to the Chinese market and the fall in commodity prices (Aguilera et al., 2017).

With this brief historical explanation of the phases of growth and economic stagnation of LA since 1990, which is associated with levels of aggregate investments, among other things, other characteristics related to expenditures at the firm level (disaggregated) are quite specific to the LA environment.

Cuervo-Cazurra et al. (2018) identified that political risks and levels of corruption influence the economic performance of LA firms. They argue that political uncertainties have a negative impact, while levels of corruption have a positive effect on firm performance. From this perspective, some economic groups can benefit from less transparent environments.

Gonzalez, Molina, Pablo, and Rosso (2017) and Chong and López-de-Silanes (2007) identified for LA that controlling shareholders' groups would be composed mainly by individual families or the state. Additionally, there is a high concentration of the voting capital of firms. This characteristic of the structure of property rights of companies in LA results in a potential agency problem between majority and minority shareholders.

Fernandez (2017) shows that, on average, research and development (R\&D) spending is low for LA firms. A lower level of investments in $R \& D$ reflects on issues involving the improvement or introduction of new products and processes. An consequence of this is the small number of patents registered in LA.

Grandes, Panigo, and Pasquini (2010) and Figlioli and Lima (2019) suggest that in LA idiosyncratic risk is not eliminated by diversification processes. This effect would be related to the low levels of liquidity verified in the financial markets of this region (Bittencourt, 2012; Escobari, Garcia, \& Mellado, 2017). From a more traditional perspective of finance, the implication of this is that the higher cost of capital reduces firms' probabilities of making investments.

With some of the identified idiosyncrasies for LA (macro and microeconomic), the lack of a business environment with greater stability over time is evident. These characteristics of LA may affect investors' 
expectations and thus their propensity to invest or the way existing businesses are managed in that environment. In this sense, the question of the value drivers of corporate investments in LA will be investigated from the theoretical model proposed by Tobin (1969), as well as about their ramifications and modifications, as can be observed in Fazzari et al. (1988).

\subsection{Hypotheses Development}

An open question in the finance literature is whether decisions on investments and financing are independent or interrelated. In this respect, Tobin's theoretical model of investments (Tobin, 1969), based on some assumptions observed in Modigliani and Miller (1958), predicts that the only driver of investments is translated by the Q ratio, that is, by the marginal return on investments under perfect market conditions. In this condition, managers should invest until the marginal benefits are equivalent to the marginal costs, regardless of the firm's capital structure.

From this perspective, the $\mathrm{Q}$ ratio contains all relevant information for making investment decisions. No variable related to the internal generation of resources, such as sales or cash flow, has explanatory power over such decisions. However, Fazzari et al. (1988) suggest that firms do not necessarily have unlimited financial capacities to make investments. In this sense, they are dependent both on their financial position and on the financing costs of investments, whether internal (such as internal cash flow generation) or external to the firm.

The question of the firm's financial position or liquidity concerning investment levels can be observed in Polk and Sapienza (2009). For the authors, firms that have high cash levels and capacity for indebtedness have incentives to allocate resources, even in projects with a negative net present value (NPV), when their stocks are overvalued in the market. This effect will be amplified if investment decisions generate a permanent overvaluation of assets, at least in the short term. Conversely, when stock prices are undervalued, there would be no incentives for new investments.

Regarding financing costs, Chowdhury, Kumar, and Shome (2016) indicate that market imperfections (informational asymmetries and agency costs) raise the costs of external financing compared to internal financing. This imbalance in financing costs affects those firms with a higher level of internal generation of resources, which are the ones that make the most investments.

Another critical step in this study refers to the results of empirical studies obtained in different environments. Moshirian et al. (2017) note that the Q ratio is a determinant of value for investments for developed countries. For underdeveloped or emerging countries, there would be a greater dependence on the generation of cash flows for the achievement of corporate investments. Mama (2017) found no evidence that the capital market conveys useful information regarding investment decisions, at least for a sample of European countries. Rousseau and Kim (2008) provide evidence that the $Q$ ratio became relevant in the Korean context only after the Asian Crisis.

For LA, Artica, Brufman, and Saguí (2019) have identified that nonfinancial firms tend to increase cash and cash equivalents as a way of preventing against financial constraints. Braun, Briones, and Islas (2019) argue that the firm's closer relations with the banking sector mitigate fundraising problems. According to Fernandez (2017), one of the main obstacles of R\&D investments is the firm's restrictions on attracting external funding.

As the results of the studies related to the subject also point to only partial evidence ${ }^{7}$, the hypotheses test the relationship between corporate investments, the $\mathrm{Q}$ ratio, and the internal generation of cash flows of the firms to the region composed by BCMP countries. It should be emphasized that the area under analysis is a favorable environment for such research because it presents characteristics with precise contours concerning levels of legal enforcement, property rights, economic and political climate, information flows (microstructures) and levels of informational and capital market efficiency (Chong \& Lopez-de-Silanes, 2007). In this sense, the idiosyncrasies found in the BCMP countries allow us to identify essential insights about investment decisions in a region of smaller quantity and transparency of information compared to more mature economies. The hypotheses are presented below in their alternative form.

Hypothesis $1(\mathrm{H} 1)$ : The $\mathrm{Q}$ ratio is a relevant driver for decisions on corporate investments in the region composed by BCMP countries.

Hypothesis 2 (H2): Internal resource generation (cash flow) is a relevant driver for decisions on corporate investments in the region composed of BCMP countries.

Hypotheses 1 and 2 will be implicitly tested if the capital structure has implications for investment decisions. Other notable findings can be observed from such tests, such as the role played by the capital market in the real economy. If such financial markets represent only a mechanism for exchanging wealth among investors, with no more of an active role in the real economy, the debate about the effect of asset price efficiency on decision 
making becomes irrelevant (Blanchard, Rhee, \& Summers, 1993; Morck, Shleifer, \& Vishny, 1990).

Another essential characteristic of the hypotheses (1 and 2) is that they seek to test important relationships about corporate investments for a specific region of LA (BCMP countries), that is, they were not developed to examine such connections from a single country. This integrated BCMP assessment enables the identification of common corporate investment drivers, i.e., a more similar risk structure between these countries.

\section{Methodological Aspects}

\subsection{Data Collection and Sample}

The data used in the study were collected on a daily, monthly and annual ${ }^{8}$ basis in the database of the electronic platform of Thomson Reuters ${ }^{\mathrm{TM}}$. All the values obtained are under the same monetary base (nominal US dollars). For certain variables, as in the case of stock prices, their values were adjusted for earnings of any nature, which mitigates econometric problems related to the discontinuity of the financial series.

The period of analysis corresponds from 2000 to 2017, which totals 18 years. This period covers important economic events such as the US financial crisis (subprime crisis) from 2008 to 2009. The formation of a sample with a more extended period was not possible, mainly due to the significant lack of data verified for LA companies (BCMP countries) before the year 2000. However, the size of the time window (18 years) for the application of econometric tests is close to other studies, such as Moshirian et al. (2017), which employed an analysis period of 21 years (1993 to 2013).

For the sample composition, information was selected from companies located in four Latin American countries: Brazil, Chile, Mexico, and Peru. In each country, only those companies that presented at least $75 \%$ of transactions carried out with their stocks ${ }^{9}$ (preferred or common stocks), considering trading days within the analysis period (2000 to 2017), were selected to compose the sample. This procedure is intended to avoid the inferences being affected low levels of stock liquidity, such as those observed in the capital markets of underdeveloped and emerging countries (Bekaert, Harvey, \& Lundblad, 2007).

In addition, procedures were adopted to exclude data from the sample as follows: i) exclusion of data from the utility and financial sectors; ii) exclusion of data in periods in which a company presented negative net equity (the results are based on the business continuity assumption - going concern); and iii) exclusion of extreme observations ${ }^{10}$ (1st and 99th percentiles). The final sample included 255 firms, as shown in Fig. 1.

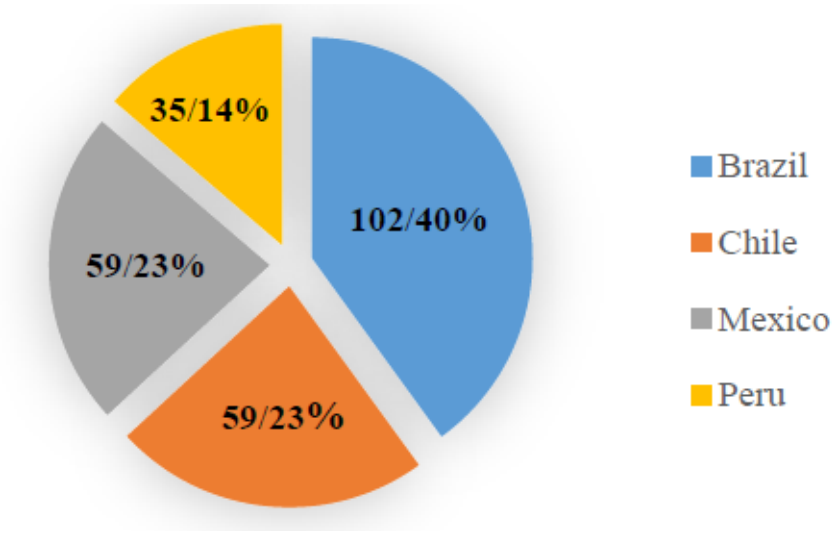

Figure 1. Composition of the sample

Note. Fig. 1 shows the total number of firms by country and the relative frequency of these observations. For example, for Brazil, there are 102 companies, which correspond to $40 \%$ of the total companies in the sample.

The analysis of Fig. 1 shows that the most significant number of companies come from Brazil, followed by Chile and Mexico, with approximately 23\% of observations. Peru has the lowest number of companies in the sample, with approximately $14 \%$ of the observations. With this selection procedure to create the sample, it was hoped to capture the most relevant characteristics of the corporate investments for the region constituted by the BCMP countries.

\subsection{Econometric Models}

\subsubsection{Base Models}

The implementation of the econometric modeling to investigate the corporate investment drivers (BCMP countries) was initially given by an expanded model of Tobin (1969). This modeling was defined as follows: 


$$
\left(\frac{I}{K}\right)_{i t}=\alpha \cdot\left(\frac{I}{K}\right)_{i, t-1}+\beta \cdot Q_{i t}+\gamma \cdot\left(\frac{C F}{K}\right)_{i t}+\eta_{i}+\Phi_{t}+\varepsilon_{t}
$$

where $(\mathrm{I} / \mathrm{K})_{\mathrm{it}}$ and $(\mathrm{I} / \mathrm{K})_{\mathrm{i}, \mathrm{t}-1}$ refer to the ratio of corporate investment to capital stock for firm $\mathrm{i}$ in period $\mathrm{t}$ and $\mathrm{t}-1$, respectively. $\mathrm{Q}_{\mathrm{it}}$ refers to the $\mathrm{Q}$ ratio for firm i in period t. $(\mathrm{CF} / \mathrm{K})_{\text {it }}$ relates to the ratio between the internal cash flow generation and the capital stock for firm i in period $t ; \eta_{i}$ represents fixed effects for the firm level. $\Phi_{t}$ represents dummy variables for the periods analysed. $\varepsilon_{\mathrm{t}}$ is the error term.

The model $1^{11}$ uses the lag for the dependent variable $((\mathrm{I} / \mathrm{K}) \mathrm{i}, \mathrm{t}-1)$, the $\mathrm{Q}$ ratio and the internal cash flow generation as explanatory variables for the investment levels of the firm. Following Arellano and Bond (1991), the fixed effects for the firm level were eliminated by a differentiation process. This modeling is presented below.

$$
\left[\left(\frac{I}{K}\right)_{i t}-\left(\frac{I}{K}\right)_{i, t-1}\right]=\alpha \cdot\left[\left(\frac{I}{K}\right)_{i, t-1}-\left(\frac{I}{K}\right)_{i, t-2}\right]+\beta \cdot\left[Q_{i t}-Q_{i, t-1}\right]+\gamma \cdot\left[\left(\frac{C F}{K}\right)_{i t}-\left(\frac{C F}{K}\right)_{i, t-1}\right]+\Phi_{t}+\left[\varepsilon_{i t}-\varepsilon_{i, t-1}\right]
$$

As the lagged component of the error term $\left.\left(\varepsilon_{\mathrm{i}, \mathrm{t}-1}\right)\right)$ is possibly correlated with the lagged term of the investments $(\mathrm{I} / \mathrm{K})_{\mathrm{t}-1}$ the generalized method of moments $(\mathrm{GMM})$ was used, as proposed by Arellano and Bond (1991). For this, the lags of the explanatory variables ( $\mathrm{t}-2$ and $\mathrm{t}-3)$ were used as instrumental variables. This procedure aims to mitigate possible problems of endogeneity in econometric modeling.

Subsequently, Model 2 received a series of control variables as a way to test the sensitivity of the coefficient $\beta$ (investment-Q ratio) and the coefficient $\gamma$ (investment-cash flow) against other variables identified in the literature as relevant for explaining the phenomenon under study. It should be emphasized that to test the robustness of the results, we have sometimes proposed different variables for the same construct. Table 1 presents the description of the variables while Appendix A provides the theoretical basis for the choice of these variables.

Table 1. Definitions of variables

\section{Variables}

CAPEX $_{\mathrm{it}}$ Fixed investments of company i for period t staggered by average total assets.

Total_Invest ${ }_{\mathrm{it}}$ Total Investments $\left(\mathrm{CAPEX}_{\mathrm{it}}+\right.$ variation in Working Capital (WC)). The calculation of the change in WC is based on the difference between current assets (CA) and current liabilities (CL) between periods $\mathrm{t}$ and $\mathrm{t}-1$. This variable (Total_Invest $\mathrm{i}_{\mathrm{i}}$ ) were staggered by average total assets.

Q1 It measures the $\mathrm{Q}$ ratio as follows: $Q 1=\frac{\left(T A_{i t}+M V_{i t}-\text { Equity }_{i t}\right)}{T A_{i t}}$, where $\mathrm{TA}_{\mathrm{it}}$ is the book value of the total assets for firm $\mathrm{i}$ in period $\mathrm{t}, \mathrm{MV}_{\mathrm{it}}$ is the market value of shareholders' equity for firm $\mathrm{i}$ in period $t$, and Equity $y_{i t}$ is the book value of equity for firm $i$ in period $t$.

Q2 Measure the Q-ratio from price-to-book values: $Q 2=\frac{\text { Price }_{i t}}{\text { Book }_{i t}}$, where Price ${ }_{i t}$ is the stock price of firm $i$ for period $t$ and Book ${ }_{\mathrm{it}}$ is the value of stockholders' equity per share of firm $\mathrm{i}$ for period $\mathrm{t}$.

CF1 A variable that measures the internal generation of cash flows for firm i in period t. Its calculation is given by the sum of the profit before the extraordinary items with depreciation and amortization. This variable was staggered by average total assets.

CF2 A variable that measures the internal generation of cash flows for firm i in period t. Its calculation is based on the following expression: $C F 2=\frac{\left[E B I T_{i t}^{*}(1-I R)\right]+\text { Dep_Amort }_{i t}}{T A_{i t}}$, where $\mathrm{EBIT}_{\mathrm{it}}$ is the 
earnings before interest and taxes of firm i for period t, IR is the marginal rate of income tax, Dep_Amort ${ }_{i t}$ is the depreciation and amortization for firm $\mathrm{i}$ in period $\mathrm{t}$, and $\mathrm{TA}_{\mathrm{it}}$ is the book value of the total assets for firm $\mathrm{i}$ in period $\mathrm{t}$.

Sales $_{\text {it }}$ A variable defined as the annual net sales value for firm $\mathrm{i}$ in period $\mathrm{t}$. This variable was staggered by average total assets.

Cash $_{\text {it }} \quad$ A variable that represents the value of cash and cash equivalents for firm $\mathrm{i}$ in period t. This variable was staggered by average total assets.

Ln_MV $V_{\text {it }} \quad$ The Napierian logarithm of the market value of company $i$ for period $t$.

Leverage $_{i t}$ Financial leverage for firm $\mathrm{i}$ in period t. Its formulation was defined as the ratio between the sum of short- and long-term debt and the book value of shareholders' equity.

Tangibility $_{\mathrm{i}} \quad$ A variable that represents the average value of expenses with fixed investments throughout analysis (2000 to 2017).

$\mathrm{ADR}_{\mathrm{it}} \quad \mathrm{A}$ dichotomous variable that assumes the value 1 if the company $\mathrm{i}$ in period $\mathrm{t}$ has an American Depositary Receipts (ADRs) program. Assume the value 0 for the remaining observations.

Rating $_{\text {it }}$ A dichotomous variable that assumes the value 1 if firm $\mathrm{i}$ in period $\mathrm{t}$ receives any credit rating that falls under "Investment Grade". These credit ratings are based on the analysis performed by the rating agencies Standard \& Poor's (S\&P), Moody's and Fitch. The other observations receive the value 0 (classified as "Speculative Grade").

Neg_CF it $_{\text {it }} \quad$ A dichotomous variable that assumes the value 1 if the company $i$ in period $t$ presents negative cash flow. Assume the value 0 for the remaining observations.

Dispersion_CF $F_{\text {it }} \quad$ A variable that represents the standard deviation of the cash flow of firm i in period t. For the calculation of the standard deviation, lagged information (five years) was used. For example, to calculate the standard deviation for the year 2005, annual cash flow information was used for the period from 2001 to 2005 .

Crisis A dichotomous variable that assumes the value 1 for the years 2008 and 2009. It assumes the value 0 for the other observations.

Rule_Law A variable that measures the levels of property rights verified in the countries under study (BCMP countries). This variable was collected from data provided by the Worldwide Governance Indicators. Detailed information is available at: http:// www.govindcators.org.

Note. Table 1 shows the descriptions of the variables with their calculation format. The variables CAPEX $_{\text {it }}$ and

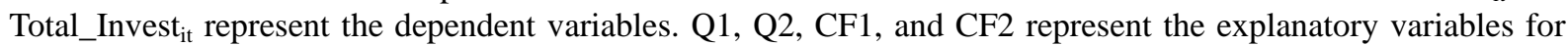
the firm's investment levels. The other variables are defined as controls in econometric modeling.

\subsubsection{Additional Econometric Models}

According to Chen et al. (2007), Ascioglu et al. (2008), and Chowdhury et al. (2016), higher levels of efficiency of stock prices reduce informational asymmetries between companies and investors. As a result, the capital market represents an important signaling mechanism for the firm's investments. To examine this effect related to stock prices, the following variables were developed:

a) Stock price informativeness $(\psi)$ : this variable is related to the magnitude with which stock prices reflect company-specific information rather than more general market information. Morck, Yeung, and Yu (2000) indicate that emerging countries generally have low levels of stock price informativeness when compared to developed countries, which may suggest that the capital markets in LA do not play a more effective role with regard to investment decisions. For the operationalization of this variable, the monthly returns of each stock (dependent variable) were regressed on the monthly returns representative of the market portfolio ${ }^{12}$ (independent variable), based on the following econometric modeling: 


$$
R_{i t}=\alpha+\beta_{1} M K T_{t}+\beta_{2} M K T_{t-1}+\varepsilon_{t}
$$

where $\mathrm{R}_{\mathrm{it}}$ is the stock return i for the period t. $\mathrm{MKT}_{\mathrm{t}}$ and $\mathrm{MKT}_{\mathrm{t}-1}$ represent the return of the market portfolio for period $t$ and $t-1$, respectively. $\varepsilon_{t}$ is the error term.

A characteristic of model 3 is that the market portfolio returns $\left(\mathrm{MKT}_{\mathrm{t}-1}\right)$ were used as an independent variable to control the results for possible delays in which stock returns reflect market information, as noted by Hou and Moskowitz (2005). Following Chan and Hameed (2006), the representative returns of the sectors of economic activity of the companies were not used as explanatory variables due to the high concentration of industry in LA.

The results of model 3 regressions were obtained from 60-month intervals (rolling regressions). For example, the results achieved for each stock in 2005 relate to the monthly data from 2001 to 2005 . The coefficients of determination (R2) obtained in model 3 (for each stock and period (2000 to 2017) suffered a logistic transformation, as recommended by Morck et al. (2000). This modeling was defined as follows:

$$
\psi_{i t}=\ln \left(\frac{1-R_{i t}^{2}}{R_{i t}^{2}}\right)
$$

where $\psi_{\mathrm{it}}$ is the stock price informativeness of stock i for period t. It represents an inverse measure of the stock price synchronicity (SPS). This last measure (SPS) was developed by Morck et al. (2000). Ln is the Napierian $\operatorname{logarithm} . \mathrm{R}^{2}$ it is the coefficient of determination for firm i in period $\mathrm{t}$.

b) The number of investment analysts (analysts $\mathrm{sit}_{\mathrm{it}}$ ): represents a measure that aims to capture whether the number of investment analysts is associated with the quality of the informational environment on the region constituted by BCMP countries. For the case of emerging countries, Piotroski and Roulstone (2004) and Chan and Hameed (2006) have identified that investment analysts have incentives to make available to the market information of a more sectoral nature rather than company-specific information. Among other reasons, it would be the fact of the high cost of capturing information relevant to the firm's level in less transparent environments.

c) Size of companies ( size $_{\mathrm{it}}$ ): this variable represents a proxy related to the levels of informational efficiency of stock prices. An example of this can be found in Fama and French $(2017,2018)$, for whom the anomalies of stock returns (market anomalies) are related predominantly to small firms, which would make the valuation of these types of companies in a rather noisy process. The variable sizeit (dichotomous variable) was defined as follows: it assumes the value 1 for the case of firm $\mathrm{i}$ in period $\mathrm{t}$ with a present market value equal to or higher than the 75th percentile to the sample under analysis. Assume the value 0 for the remaining observations.

Following Chen et al. (2017), Ascioglu et al. (2018), and Chowdhury et al. (2016) was expected that the interactions between the variables $\psi_{\text {it }}$ and $\mathrm{Q}^{13}$, analyst $\mathrm{s}_{\text {it }}$ and $\mathrm{Q}$, and size $\mathrm{it}_{\mathrm{it}}$ and $\mathrm{Q}$ present coefficients with statistical significance and a positive sign. This result would bring additional evidence as to how the capital market is related to firms' investment decisions.

Another question critical to the study was the investigation as to whether the investment- $Q$ and investment-cash flow relationships are tied to the magnitude of the investments. Grullon et al. (2018) suggest that more substantial investments are concentrated in some companies or certain periods. This consideration becomes relevant for the study since the LA presented different phases of economic growth, as shown by Manuelito and Jiménez (2015) and Brenes et al. (2016). To carry out this investigation, we used the Logit model, defined as follows:

$$
\text { Invest_Size }_{i t}=\beta_{1} Q_{i t}+\beta_{2} C F_{i t}+\text { Zcontrol }+\varepsilon_{t}
$$

where Invest_Size ${ }_{i t}$ is a dichotomous variable that assumes the value 1 for the case of firm $\mathrm{i}$ in period $\mathrm{t}$ presenting investments equal to or greater than the 75th percentile to the investments made by the firms that integrate the sample in the period from 2000 to 2017. Assume the value 0 for the remaining observations. The variables CAPEX ${ }_{\mathrm{it}}$ and Total_Invest ${ }_{\mathrm{it}}$ were considered for the calculation of percentiles. $\mathrm{Q}_{\mathrm{it}}$ is the $\mathrm{Q}$ ratio for firm $\mathrm{i}$ in period $\mathrm{t}\left(\mathrm{Q} 1\right.$ and $\mathrm{Q} 2$, defined in section 3.2.1). $\mathrm{CF}_{\text {it }}$ is the internal generation of cash flows for company $\mathrm{i}$ in 
period $\mathrm{t}(\mathrm{CF} 1$ and $\mathrm{CF} 2$, defined in section 3.2.1). Zcontrol is the vector of control variables (variables defined in section 3.2.1). $\varepsilon_{t}$ is the error term.

It was expected that the coefficients $\beta 1$ and $\beta 2$ present statistical significance and a positive sign, which would indicate that the $\mathrm{Q}$ ratio and the internal generation of cash flows are relevant drivers for the levels of corporate investments in BCMP countries.

\section{Results}

\subsection{Descriptive Statistics}

Descriptive statistics are presented in Table 2.

Table 2. Descriptive statistics

\begin{tabular}{|c|c|c|c|c|c|}
\hline Variables & Mean & Standard deviation & $\mathrm{CV}$ & Minimum & Maximum \\
\hline CAPEX $_{\text {it }}$ & 0.0644 & 0.0607 & 0.9425 & 0.0004 & 0.3414 \\
\hline Total_Invest ${ }_{\mathrm{it}}$ & 0.0757 & 0.1402 & 1.8520 & -0.2630 & 0.6665 \\
\hline Q1 & 1.3300 & 0.8102 & 0.6091 & 0.3375 & 5.1934 \\
\hline Q2 & 2.1334 & 3.4582 & 1.6209 & 0.0277 & 26.7697 \\
\hline CF1 & 0.1002 & 0.0999 & 0.9970 & -0.1695 & 0.5139 \\
\hline $\mathrm{CF} 2$ & 0.0864 & 0.0912 & 1.0555 & -0.2222 & 0.4154 \\
\hline Sales $_{\text {it }}$ & 0.8435 & 0.6018 & 0.7134 & 0.0086 & 3.4652 \\
\hline Cash $_{\text {it }}$ & 0.1182 & 0.1305 & 1.1040 & 0.0004 & 0.6915 \\
\hline $\mathrm{Ln} \_\mathrm{MV}_{\mathrm{it}}$ & 19.6569 & 2.2387 & 0.1138 & 14.0727 & 24.6079 \\
\hline Leverage $_{\mathrm{it}}$ & 1.0059 & 1.7204 & 1.7103 & 0.0004 & 12.9225 \\
\hline Tangibility $_{\mathrm{i}}$ & 0.7539 & 0.4697 & 0.6230 & 0.0060 & 2.2594 \\
\hline Dispersion_CF ${ }_{i t}$ & 0.0434 & 0.0475 & 1.0944 & 0.0033 & 0.3009 \\
\hline Rule_Law & 0.0441 & 0.7383 & 16.7415 & -0.7300 & 1.4300 \\
\hline $\mathrm{ADR}_{\mathrm{it}}$ & 0.1220 & - & - & - & - \\
\hline Rating $_{\text {it }}$ & 0.2560 & - & - & - & - \\
\hline $\mathrm{Neg}_{-} \mathrm{CF}_{\text {it }}$ & 0.0659 & - & - & - & - \\
\hline Crisis & 0.1111 & - & - & - & - \\
\hline
\end{tabular}

Note. Table 2 presents for each variable the following descriptive statistics: mean, standard deviation, the coefficient of variation (CV), minimum, and maximum. For the dichotomous variables $\left(\mathrm{ADR}_{\mathrm{it}}, \mathrm{R}_{\mathrm{iting}} \mathrm{it}\right.$, Neg_CF $F_{i t}$, and Crisis) were calculated only their means, which are translated by the observed frequencies for these variables. The variable Dispersion_ $\mathrm{CF}_{\text {it }}$ (standard deviation of the cash flow) was derived from the variable CF1.

The dependent variables CAPEX ${ }_{\text {it }}$ and Total_Invest ${ }_{\text {it }}$ presented relatively close averages $(0.0644$ and 0.0757 , respectively). The measure of the standard deviation was different for these two variables $(0.0607$ and 0.1402 , respectively). The greater deviation of the variable Total_Invest $t_{i t}$ is the result of the change of investments in

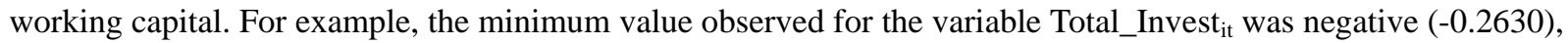
which denotes disinvestment in working capital. One plausible explanation for this lies in the economic cycles in LA.

In the analysis of the coefficient of variation (CV), the Q1 variable showed a lower dispersion compared to the Q2 variable (0.6091 and 1.6209, respectively). The variables related to the internal cash generation levels, CF1 and CF2, showed closer CV (0.9970 and 1.0555, respectively).

Regarding the controls used in econometric modeling, the variable Rule_Law presented the highest CV (16.7415). This result is in agreement with Chong and Lopez-de-Silanes (2007) regarding the low levels of property rights identified in LA countries. The variables Cash $_{i t}$, Leverage $_{i t}$, and Dispersion_CF $F_{i t}$, showed relatively high $\mathrm{CV}$, while the variable associated with the market value of firms, $L n_{-} \mathrm{MV}_{\mathrm{it}}$, showed the lowest CV. Additionally, high mean values were identified for the Tangibility $y_{i}$ variable (mean of 0.7539). Moshirian et al. (2017) note that corporate investments in emerging countries are concentrated in tangible assets, which would partly explain the results obtained for the variable Tangibility ${ }_{\mathrm{i}}$. 
Other important characteristics of the sample were identified as follows: i) approximately $12 \%$ of the companies have ADR programs; ii) approximately $25 \%$ of companies are classified as "Investment Grade"; iii) the cash flow of the firms was negative in approximately $6.5 \%$ of the observations; and (iv) the period known as "Crisis" totaled approximately $11 \%$ for the entire period analyzed (2000 to 2017).

Another analysis conducted was the estimation of the correlation coefficients, which is presented in Table 3. This analysis was restricted in identifying the correlation coefficients of Pearson and Spearman for the continuous variables.

Table 3. Correlations

\begin{tabular}{|c|c|c|c|c|c|c|c|c|c|c|c|c|}
\hline Variables & (1) & (2) & (3) & (4) & (5) & (6) & (7) & (8) & (9) & (10) & (11) & (12) \\
\hline $\operatorname{CAPEX}_{\mathrm{it}}(1)$ & 1 & $0.401 * * *$ & $0.240^{* * *}$ & $0.154^{* * *}$ & $0.382^{* * *}$ & $0.333^{* * *}$ & $0.202 * * *$ & $0.142 * * *$ & $0.168^{* * *}$ & $-0.051^{* * *}$ & $0.231 * * *$ & $0.084^{* * * *}$ \\
\hline Total_Invest ${ }_{i t}(2)$ & $0.413 * * *$ & 1 & $0.1912 * * *$ & $0.103 * * *$ & $0.418^{* * *}$ & $0.373^{* * * *}$ & $0.247 * * *$ & $0.344 * * *$ & $0.137 * * *$ & $-0.070 * * *$ & $0.071 * * *$ & $0.050 * * *$ \\
\hline Q1 (3) & $0.341 * * *$ & $0.213 * * *$ & 1 & $0.499 * * *$ & $0.405^{* * *}$ & $0.380 * * *$ & $0.228 * * *$ & $0.256^{* * * *}$ & $0.504 * * *$ & -0.014 & $-0.056 * * *$ & -0.003 \\
\hline Q2 (4) & $0.323^{* * *}$ & $0.211 * * *$ & $0.872 * * *$ & 1 & $0.124 * * *$ & $0.148^{* * *}$ & $0.150 * * *$ & $0.147 * * *$ & $0.198 * * *$ & $0.228 * * *$ & $-0.040^{* *}$ & 0.029 \\
\hline CF1 (5) & $0.474 * * *$ & $0.441 * * *$ & $0.473 * * *$ & $0.417 * * *$ & 1 & $0.842 * * *$ & $0.330 * * *$ & $0.328 * * *$ & $0.267 * * *$ & $-0.238 * * *$ & $0.135 * * *$ & -0.012 \\
\hline CF2 (6) & $0.480 * * *$ & $0.454 * * *$ & $0.469 * * *$ & $0.450 * * *$ & $0.856 * * *$ & 1 & $0.300 * * *$ & $0.242 * * *$ & $0.346 * * *$ & $-0.135 * * *$ & $0.065^{* * *}$ & $-0.129 * * *$ \\
\hline Sales $_{\text {it }}(7)$ & $0.278^{* * *}$ & $0.266^{* * *}$ & $0.280 * * *$ & $0.296 * * *$ & $0.390 * * *$ & $0.424^{* * *}$ & 1 & $0.183^{* * *}$ & $0.030^{*}$ & $-0.069 * * *$ & -0.018 & $-0.064^{* * *}$ \\
\hline Cash $_{\text {it }}(8)$ & $0.124^{* * *}$ & $0.213 * * *$ & $0.321 * * *$ & $0.322 * * *$ & $0.263 * * *$ & $0.219 * * *$ & $0.168 * * *$ & 1 & $0.205 * * *$ & $-0.033^{* *}$ & $-0.132 * * *$ & $0.068 * * *$ \\
\hline $\mathrm{Ln}_{-} \mathrm{MV}_{\mathrm{it}}(9)$ & $0.245^{* * *}$ & $0.112^{* * *}$ & $0.586 * * *$ & $0.544 * * *$ & $0.249 * * *$ & $0.268 * * *$ & $0.060 * * *$ & $0.376^{* * * *}$ & 1 & $-0.071 * * *$ & $-0.051 * * *$ & $-0.257 * * *$ \\
\hline Leverage $_{\mathrm{it}}(10)$ & $-0.079 * * *$ & $-0.116 * * *$ & -0.015 & $0.059 * * *$ & $-0.337 * * *$ & $-0.153 * * *$ & $-0.077 * * *$ & $0.039 *$ & $0.083 * * *$ & 1 & $-0.056 * * *$ & $0.089 * * *$ \\
\hline Tangibility $_{\mathrm{i}}(11)$ & $0.352 * * *$ & $0.239 * * *$ & $-0.084 * * *$ & $-0.109 * * *$ & $0.310^{* * *}$ & $0.366 * * *$ & $0.097 * * *$ & $-0.225^{* * *}$ & $-0.116 * * *$ & $-0.109 * * *$ & 1 & $0.123 * * *$ \\
\hline Dispersion_CF $\mathrm{it}_{\mathrm{it}}(12)$ & 0.016 & 0.035 & $-0.054 * *$ & $-0.063 * * *$ & 0.001 & -0.023 & $-0.045^{* *}$ & 0.008 & $-0.188 * * *$ & -0.030 & $0.106 * * *$ & 1 \\
\hline
\end{tabular}

Note. Table 3 presents the Pearson (upper diagonal) and Spearman (lower diagonal) correlation coefficients for the continuous variables. Although the variable Rule_Law is classified as continuous, its values are truncated in the range of -2.5 (low levels of property rights) to 2.5 (high levels of property rights). Therefore, this variable was not considered in the present analysis. The variable representative of the cash flow dispersion (Dispersion_CF $\mathrm{it}_{\mathrm{it}}$ ) was calculated from the data obtained for variable CF1. The significance levels for the results are represented as follows: $* * *$ significant at $1 \%, * *$ significant at 5\%, significant at $10 \%$.

The results obtained in the correlation analysis showed positive and statistically significant coefficients between the dependent variables CAPEX ${ }_{\mathrm{it}}$ and Total_Invest ${ }_{\mathrm{it}}$ and the variables Q1, Q2, CF1, CF2, Sales $\mathrm{it}_{\mathrm{it}}, \mathrm{Cash}_{\mathrm{i}}, \mathrm{Ln}_{-} \mathrm{MV}_{\mathrm{it}}$, and Tangibility ${ }_{\mathrm{i}}$. The variable Leverage ${ }_{\mathrm{it}}$ showed coefficients with the negative signal regarding the dependent variables, while the results obtained for the variable Dispersion_ $\mathrm{CF}_{\text {it }}$ were not significant regarding the dependent variables. The identified correlations note that apart from the investment opportunities measured by the variables Q1 and Q2, the capital structure ${ }^{14}$ can impact corporate investments.

The variables related to the $\mathrm{Q}$ ratio (Q1 and $\mathrm{Q} 2)$ and internal cash flow generation (CF1 and CF2) showed high correlations with each other. This result was expected since these variables were used to measure the same construct.

Other structures of relations between variables were identified. For example, the market value of companies $\left(\mathrm{Ln} \_\mathrm{MV}_{\mathrm{it}}\right)$ is positively associated with variables $\mathrm{Q} 1, \mathrm{Q} 2, \mathrm{CF} 1$ and $\mathrm{CF} 2$, which suggests a greater investment capacity for larger firms. The dispersion of the cash flow (Dispersion_C $\mathrm{CF}_{\mathrm{it}}$ ) is also smaller for these types of companies. On the other hand, the variable Tangibility $y_{i}$ showed coefficients with the negative signal about the variables Q1 and Q2 and coefficients with the positive signal about the variables CF1 and CF2. This result becomes relevant when considering the high level of tangibility of the investments verified in the sample (approximately $75 \%$ ).

Additionally, the structure of corporate investments in LA (BCMP countries) was analyzed over the period under study. Fig. 2 shows this information. 


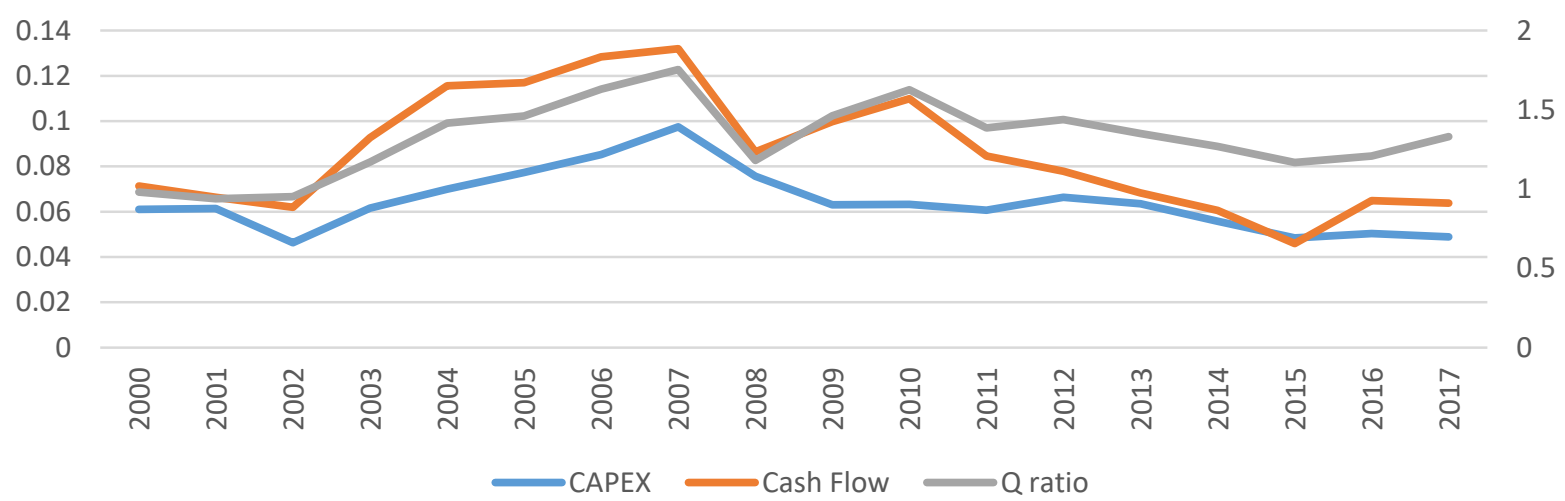

Figure 2. Average corporate investment in LA (BCMP countries) from 2000 to 2017

Note. Fig. 2 shows the dynamics of average corporate investment in LA. Calculations of the averages of the variables used the following variables: CAPEX (CAPEXit), Q Ratio (Q1) and cash flow (CF1). The main (left) axis refers to CAPEX and cash flow values. The secondary (right) axis relates to the values found for the $\mathrm{Q}$ ratio.

Fig. 2 shows that the levels of investments in fixed capital (CAPEX), cash flow and Q ratio showed a tendency to increase for the period from 2002 to 2007. As of 2008, there was a reduction of the values for these variables. Some signs of recovery have been verified for cash flow and Q ratio levels from 2015. However, current levels of fixed capital investment in BCMP countries remain similar to those in the early 2000s. This result is in line with studies by Manuelito and Jiménez (2015), Brenes et al. (2016), and Aguilera et al. (2017) for the economic cycles in LA. The next section will examine these questions further through regression analysis.

\subsection{Regression Analysis}

Table 4 presents the results obtained from the regression analysis and refers to the base models (section 3.2.1). These models were adequate for the inference process since the Hansen test pointed to the exogeneity of the instrumental variables (lags of the explanatory variables) and the AR(2) test indicated the absence of autocorrelation of the residuals. In this sense, there is evidence that the results achieved are not biased by possible endogeneity problems.

Table 4. Regression analysis: base models

\begin{tabular}{|c|c|c|c|c|c|c|c|c|c|c|}
\hline Variables & (1) & (2) & (3) & (4) & (5) & (6) & (7) & (8) & (9) & (10) \\
\hline L.CAPEX $_{\text {it }}$ & $0.347^{* * * *}$ & $0.290^{* * *}$ & $0.271^{* * *}$ & $0.226 * * *$ & $0.233^{* * * *}$ & $0.226^{* * *}$ & & & & \\
\hline L.Total_Invest $\mathrm{it}_{\mathrm{it}}$ & & & & & & & $-0.123 * * *$ & $-0.137^{* * *}$ & $-0.140^{* * * *}$ & $-0.150^{* * *}$ \\
\hline Q1 & 0.003 & 0.009 & 0.003 & -0.003 & -0.006 & -0.003 & $-0.034^{*}$ & -0.028 & & \\
\hline Q2 & & & & & & & & & 0.001 & -0.001 \\
\hline CF1 & $0.191^{* * *}$ & $0.211^{* * *}$ & $0.133^{* *}$ & $0.243^{* * *}$ & $0.221^{* * *}$ & $0.243 * * *$ & & & & \\
\hline CF2 & & & & & & & $0.648^{* * * *}$ & $0.387^{* *}$ & $0.529^{* * *}$ & $0.326^{* *}$ \\
\hline Sales $_{\text {it }}$ & & & 0.0171 & $0.033^{* *}$ & $0.040^{* * * *}$ & $0.033^{* *}$ & $0.106 * * *$ & $0.085^{* * *}$ & $0.093^{* * *}$ & $0.080^{* * * *}$ \\
\hline Cash $_{\text {it }}$ & & & -0.005 & 0.0158 & 0.0062 & 0.016 & & $0.531^{* * * *}$ & & $0.479 * * *$ \\
\hline $\mathrm{Ln}_{-} \mathrm{MV}_{\text {it }}$ & & & & 0.0036 & 0.0063 & 0.004 & 0.022 & 0.003 & 0.020 & -0.001 \\
\hline Leverage $_{\text {it }}$ & & & & -0.001 & -0.002 & -0.001 & -0.002 & -0.007 & -0.008 & $-0.011^{*}$ \\
\hline Tangibility $_{\mathrm{i}}$ & & & & $0.073^{* * *}$ & $0.052^{* * *}$ & $0.073^{* * *}$ & -0.015 & 0.029 & 0.003 & 0.012 \\
\hline $\mathrm{ADR}_{\mathrm{it}}$ & & & & 0.137 & 0.265 & 0.137 & 0.019 & 0.410 & -0.230 & 0.356 \\
\hline Rating $_{\text {it }}$ & & & & -0.004 & -0.001 & -0.004 & -0.049 & -0.044 & -0.015 & -0.027 \\
\hline $\mathrm{Neg}_{-} \mathrm{CF}_{\text {it }}$ & & & & $0.041^{*}$ & $0.041^{* *}$ & $0.041^{*}$ & -0.018 & 0.001 & -0.033 & -0.021 \\
\hline Dispersion_CF ${ }_{\text {it }}$ & & & & & 0.119 & 0.073 & 0.255 & 0.080 & 0.315 & 0.130 \\
\hline Rule_Law & & & & & & 0.026 & -0.046 & -0.039 & 0.025 & 0.028 \\
\hline Crisis & & & & & & $-0.040 * * *$ & -0.030 & -0.060 & -0.051 & -0.020 \\
\hline Years & Yes & Yes & Yes & Yes & Yes & Yes & Yes & Yes & Yes & Yes \\
\hline No. of observations & 2,379 & 1,024 & 2,343 & 1,750 & 1,750 & 1,750 & 2,058 & 2,058 & 2,058 & 2,058 \\
\hline Hansen test- Prob. $\mathrm{Chi}^{2}$ & 0.453 & 0.577 & 0.144 & 0.617 & 0.905 & 0.812 & 0.514 & 0.399 & 0.455 & 0.412 \\
\hline AR(2) test- Prob. Z & 0.445 & 0.621 & 0.605 & 0.812 & 0.828 & 0.491 & 0.999 & 0.997 & 0.770 & 0.810 \\
\hline
\end{tabular}

Note. The models (1 to 10) used dynamic panel data with the generalized method of moments (GMM) estimation. The results obtained refer to the period from 2000 to 2017, except for the model (2), which used observations for the years 2000 to 2007. The variables L.CAPEX ${ }_{\text {it }}$ and L.Total_Invest $t_{i t}$ relate to the lag in one period of CAPEX and Total_Invest $t_{\mathrm{it}}$, respectively. The significance levels for the results are represented as follows: $* * *$ significant 
at $1 \%, * *$ significant at $5 \%, *$ significant at $10 \%$.

Models 1 to 6 , presented in Table 4, used the levels of investments in fixed capital $\left(\mathrm{CAPEX}_{\mathrm{it}}\right)$ as a dependent variable. For these models, the variables L.CAPEX it $_{\text {and }}$ CF1 presented coefficients with a positive sign and statistical significance at the $1 \%$ level. However, the Q-related variable (Q1) did not show relevant results. This result for the variables Q1 and CF1 was verified even when, in model 2, a period of more significant economic growth in LA was considered between 2000 and 2007. Significant coefficients for the variables Sales ${ }_{i t}$, Tangibility, $\mathrm{Neg}_{\mathrm{C}} \mathrm{CF}_{\mathrm{it}}$, and Crisis were identified through the models 4, 5 and 6.

For models 7 to 10 , total investments (Total_Invest ${ }_{i t}$ ) were used as the dependent variable. The main results for these models are the variables L.Total_Invest $t_{i t}, \mathrm{CF} 2$ and $\mathrm{Sales}_{\mathrm{it}}$, which showed positive and significant coefficients. The variable Q1 presented a negative coefficient and only marginal statistical significance at the $10 \%$ level in model 7. The $\mathrm{Cash}_{\mathrm{it}}{ }^{15}$ variable was significant in models 8 and 10 .

Other results (not reported) for the different possible combinations between the CAPEX it $_{\text {and Total_Invest }}$ it dependent variables with the explanatory variables Q1, Q2, CF1, and CF2 suggest that the internal generation of cash flows is one of the main drivers of corporate investments for the region formed by the BCMP countries. In contrast, there were no indications that the capital market represents a mechanism for transmitting information that is useful for decision making about the real side of the economy.

It was also tested whether information derived from the capital market is associated with corporate investments when considering the levels of informational efficiency of stock prices. The results are reported in Table 5.

Table 5. Q ratio and the informational efficiency levels of stock prices

\begin{tabular}{|c|c|c|c|c|}
\hline Variables & (1) & (2) & (3) & (4) \\
\hline L.CAPEX $_{\text {it }}$ & $0.218 * * *$ & $0.239 * * *$ & $0.228 * * *$ & $0.217 * * *$ \\
\hline Q1 & 0.002 & & 0.005 & 0.001 \\
\hline Q1. $\psi_{i t}$ & $0.003 * *$ & & & \\
\hline Q1. analysts ${ }_{i t}$ & & & -0.006 & \\
\hline${\text { Q1. } \text { size }_{\text {it }}}$ & & & & -0.005 \\
\hline Q2 & & -0.001 & & \\
\hline Q2. $\psi_{i t}$ & & 0.001 & & \\
\hline $\mathrm{CF} 1$ & $0.202 * * *$ & $0.211 * * *$ & $0.191 * * *$ & $0.200 * * *$ \\
\hline Sales $_{\text {it }}$ & $0.033 * * *$ & $0.035 * * *$ & $0.032 * * *$ & $0.040 * * *$ \\
\hline $\operatorname{Cash}_{\text {it }}$ & -0.027 & -0.037 & 0.040 & 0.034 \\
\hline Ln_MV & 0.002 & $0.010^{*}$ & 0.002 & -0.004 \\
\hline Leverage $_{i t}$ & -0.001 & 0.001 & 0.001 & 0.001 \\
\hline Tangibility $_{i}$ & $0.063 * * *$ & $0.060 * * *$ & $0.073 * * *$ & $0.065^{* * *}$ \\
\hline $\mathrm{ADR}_{\mathrm{it}}$ & 0.002 & 0.102 & -0.013 & 0.192 \\
\hline Rating $_{\text {it }}$ & 0.001 & 0.001 & -0.008 & -0.002 \\
\hline $\mathrm{Neg} \mathrm{CF}_{\mathrm{it}}$ & $0.026^{*}$ & $0.034 * *$ & $0.032^{*}$ & $0.030 * *$ \\
\hline Years & YES & YES & YES & YES \\
\hline No. of observations & 1,750 & 1,750 & 1,750 & 1,750 \\
\hline Hansen test- Prob. Chi2 & 0.691 & 0.572 & 0.538 & 0.409 \\
\hline AR(2) test- Prob. $\mathrm{Z}$ & 0.849 & 0.998 & 0.912 & 0.884 \\
\hline
\end{tabular}

Note. The models (1 to 4) used dynamic panel data with the generalized method of moments (GMM) estimation.

The variable L.CAPEXit refers to the lag in one period for the variable CAPEXit. The variables Dispersion_CFit, Rule_Law and Crisis were not considered in this test to identify whether the structures of relations between these variables are interfering in the results. For example, in periods of crisis, a greater dispersion of cash flows is expected. However, the inclusion of these variables did not qualitatively alter the results. The direct effect of the variables $\psi$ it, analystsit, and sizeit on the level of fixed investments (CAPEXit) do not change the results (not reported). The significance levels for the results are represented as follows: *** significant at $1 \%$, ** significant at $5 \%$, * significant at $10 \%$. 
The interactions between the variables associated with the $\mathrm{Q}$ ratio $(\mathrm{Q} 1$ and $\mathrm{Q} 2)$ and the stock information efficiency levels ( $\psi$ it, analysts ${ }_{\mathrm{it}}$, and size $_{\mathrm{it}}$ ) were not relevant in explaining corporate investments. Only the interaction Q1. $\psi_{\mathrm{it}}$ exhibited coefficients with statistical significance (model 1). However, the small value found for this coefficient does not bring more robust evidence for this interaction. It should be emphasized that the interaction coefficient Q2. $\psi_{\text {it }}$ (model 2) was not significant.

Models 3 and 4, from Table 5, indicate that even larger companies and those with more significant numbers of analysts rely more prominently on internal resource generation than on information provided by the capital market in decision making on investments. In this sense, the a priori classification of companies as "financially restricted" when these demonstrate high sensitivity investments-cash flow is quite questionable. This same line of argument can be verified in Kaplan and Zingales (1997), Kadapakkam et al. (1998) and Cleary (1999).

Another study carried out concerns the magnitude of the investments made by the firms and their drivers. These results are shown in Table 6.

Table 6. Magnitude of corporate investments

\begin{tabular}{|c|c|c|c|c|}
\hline Variables & $\begin{array}{c}(1) \\
\mathrm{CAPEX}>=50 \%\end{array}$ & $\begin{array}{c}(2) \\
\mathrm{CAPEX}>=50 \%\end{array}$ & $\begin{array}{c}(3) \\
\text { CAPEX }>=75 \%\end{array}$ & $\begin{array}{c}(4) \\
\text { CAPEX }>=75 \%\end{array}$ \\
\hline L.CAPEX $_{\text {it }}$ & & $17.817 * * *$ & & $13.927 * * *$ \\
\hline Q1 & 0.085 & 0.164 & -0.126 & $-0.353 *$ \\
\hline $\mathrm{CF} 1$ & $4.473 * * *$ & 2.578* & $5.573 * * *$ & $3.813 * *$ \\
\hline Sales $_{\text {it }}$ & $1.974 * * *$ & $2.185 * * *$ & $1.809 * * *$ & $2.526 * * *$ \\
\hline Cash $_{\text {it }}$ & -0.041 & 0.459 & -0.096 & 0.218 \\
\hline${\mathrm{Ln} \_M V_{\text {it }}}$ & $0.534 * * *$ & $0.372 * * *$ & $0.326 * *$ & $0.375 * *$ \\
\hline Leverage $_{i t}$ & -0.031 & -0.068 & -0.036 & -0.119 \\
\hline Tangibility $_{i}$ & $2.182 * * *$ & $2.570 * * *$ & $1.905^{* * *}$ & $2.174 * * *$ \\
\hline $\mathrm{ADR}_{\mathrm{it}}$ & $-2.626 * *$ & -1.653 & -13.830 & -11.973 \\
\hline Rating $_{\text {it }}$ & 0.268 & 0.099 & 0.416 & 0.184 \\
\hline $\mathrm{Neg}_{-} \mathrm{CF}_{\text {it }}$ & $0.881 * * *$ & 0.488 & $1.257 * * *$ & $0.886^{*}$ \\
\hline Dispersion_CF $\mathrm{CF}_{\mathrm{it}}$ & -2.448 & $-7.871 * *$ & -2.244 & $2.174 * * *$ \\
\hline Years & YES & YES & YES & YES \\
\hline No. Of observations & 1,834 & 1,709 & 1,834 & 1,709 \\
\hline $\mathrm{Chi}^{2}$ statistics & $339.21 * * *$ & $438.14 * * *$ & $257.12 * * *$ & $342.55 * * *$ \\
\hline
\end{tabular}

Note. Table 6 shows the results of the regression analysis about the magnitude of the investments made by the firms composing the sample. For this, we used the Logit regression technique. For greater robustness of the results two variants for the dependent variable were considered. In models 1 and 2 the dependent variable assumes the value 1 for the case of firm $i$ in period $t$ to present investments equal to or greater than the 50th percentile. Assume the value 0 for the remaining observations. For models 3 and 4 , the percentile used to measure the dependent variable is from the 75th percentile. The results of models 2 and 4 were also controlled by the lag in one period for investments in fixed capital (L.CAPEXit). The variables Rule_Law and Crisis were not considered in this test. However, the inclusion of these variables did not qualitatively alter the results (not reported). The results (not reported) were qualitatively similar when the measurement of the dependent variable was obtained from the total investments (Total_Investit). The significance levels for the results are represented as follows: *** significant at $1 \%, * *$ significant at $5 \%, *$ significant at $10 \%$.

Through the results shown in Table 6, there is evidence that cash flow generation, firm size, sales level, and asset tangibility are positively associated with the magnitude of corporate investments made by firms, since the

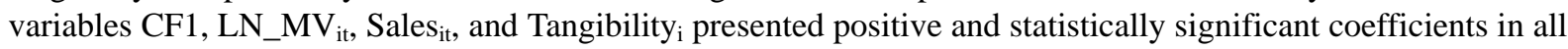
models (models 1 to 4). For the Q ratio, measured by the variable Q1, a significant coefficient was identified only in model 4. The sign of this coefficient is negative, which supports the notion of a lesser interaction between the information made available by the market and the corporate investments.

\subsection{Additional Tests}

Lewellen and Lewellen (2016) note that the significance found in the empirical tests for measures of internal 
resource generation (cash flows) is just because this variable is correlated with investment opportunities, that is, with the $\mathrm{Q}$ ratio. To address this issue a dependent variable based on the free cash flow to the firm (FCFF) was developed. This modeling was defined as follows:

$$
F C F F_{i t}=\frac{\left[\left(E B I T_{i t} *(1-I R)\right)+D e p_{-} A m o r t_{i t}\right]-\left[C A P E X_{i t}+\left(\left(C A_{i t}-C L_{i t}\right)-\left(C A_{i, t-1}-C L_{i, t-1}\right)\right)\right]}{T A_{i t}}
$$

where $\mathrm{FCFF}_{\mathrm{it}}$ is the free cash flow from firm $\mathrm{i}$ in period t. EBIT $\mathrm{it}$ is the earnings before interest and taxes of firm $i$ for period $t$. IR is the marginal rate of income tax. Dep_Amort $t_{i t}$ is the depreciation and amortization for firm $i$ in period t. CAPEX $\mathrm{it}_{\mathrm{t}}$ is the fixed investments of company $\mathrm{i}$ in period t. $\mathrm{CA}_{\mathrm{it}}$ and $\mathrm{CA}_{\mathrm{i}, \mathrm{t}-1}$ is the current assets for firm $i$ in period $t$ and $t-1$, respectively. $C L_{i t}$ and $C_{i, t-1}$ is the current liabilities for company i in period $t$ and $t-1$, respectively. $\mathrm{TA}_{\mathrm{it}}$ is the total assets for firm $\mathrm{i}$ in period $\mathrm{t}$.

The FCFF $_{\text {it }}$ measure integrates both the internal generation of cash flows and the expenses incurred with fixed and working capital investments. The results are shown in Table 7.

Table 7. Free cash flow to the firm (FCFF) and Q ratio

\begin{tabular}{|c|c|c|c|c|c|c|}
\hline Variables & (1) & (2) & (3) & (4) & (5) & (6) \\
\hline L.FCFF $_{\text {it }}$ & $-0.143 * * *$ & -0.146 & $-0.141 * * *$ & $-0.150 * * *$ & $-0.128 * *$ & $-0.096^{*}$ \\
\hline Q1 & 0.023 & 0.019 & & & -0.072 & \\
\hline Q2 & & & -0.001 & -0.002 & & 0.003 \\
\hline $\mathrm{Cash}_{\mathrm{it}}$ & $-0.419 * * *$ & $-0.395 * * *$ & $-0.391 * * *$ & $-0.390 * * *$ & $-0.852 * * *$ & $-0.802 * * *$ \\
\hline $\mathrm{Ln} \_\mathrm{MV}$ it & -0.028 & -0.019 & -0.005 & 0.001 & $0.084 *$ & $0.077 *$ \\
\hline Leverage $_{\text {it }}$ & -0.007 & -0.007 & -0.001 & -0.001 & -0.018 & -0.018 \\
\hline Tangibility $_{i}$ & -0.027 & -0.015 & -0.027 & -0.007 & -0.035 & 0.129 \\
\hline $\mathrm{ADR}_{\mathrm{it}}$ & & -1.123 & & -1.249 & & \\
\hline Rating $_{\text {it }}$ & & -0.001 & & -0.009 & & \\
\hline Years & Yes & Yes & Yes & Yes & Yes & Yes \\
\hline No. Of observations & 2,537 & 2,537 & 2,474 & 2,474 & 925 & 925 \\
\hline Hansen test- Prob. Chi2 & 0.153 & 0.525 & 0.211 & 0.489 & 0.439 & 0.322 \\
\hline AR(2) test- Prob. Z & 0.911 & 0.896 & 0.926 & 0.979 & 0.970 & 0.631 \\
\hline
\end{tabular}

Note. The models ( 1 to 6 ) used dynamic panel data with the generalized method of moments (GMM) estimation.

The results obtained for models 1 to 4 refer to the period from 2000 to 2017. Models 5 and 6 used observations

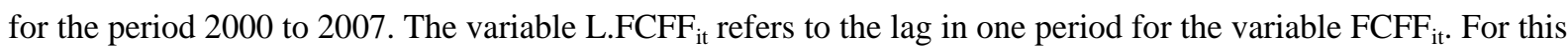
test, we did not use variables related to the internal generation of resources (CF1 and CF2), Sales it $_{\text {, Neg_CF }}$, Dispersion_CF $F_{\text {it }}$, Rule_law, and Crisis. The significance levels for the results are represented as follows: *** significant at $1 \%, * *$ significant at $5 \%$, * significant at $10 \%$.

The variables that measure the $\mathrm{Q}$ ratio $(\mathrm{Q} 1$ and $\mathrm{Q} 2)$ did not present statistically significant coefficients. In this sense, no evidence was found that the Q ratio could explain the levels of cash flows of the firm as well as its investments. The main result was verified for the $\mathrm{Cash}_{\mathrm{it}}$ variable, which showed a negative and significant coefficient in all the models. According to Artica et al. (2019), the levels of retention of cash and cash equivalents for LA firms are attributable to precautionary reasons, mainly due to greater uncertainties associated with the generation of cash flows.

Another concern regarding the obtained results is related to possible measurement errors for the variables associated with the Q ratio (Q1 and Q2). Abel (2018) indicates that empirical models that seek to investigate the drivers of corporate investments do so from an average measure for the $\mathrm{Q}$ ratio. However, the $\mathrm{Q}$ ratio is a marginal but not directly observable concept. To overcome this problem, the estimator developed by Erickson and Whited (2000, 2002, 2012) was used. The (unreported) results indicated that the Q ratio does not provide relevant information for investment decisions. 


\subsection{Discussion}

The capital market seems to have a minimal effect on investment decisions for BCMP countries. Supporting this view is a series of idiosyncrasies present in this environment, such as the low level of development of the financial markets, high concentration of corporate voting capital, and low level of legal enforcement and property rights, among others (Gonzalez et al. 2017; Chong \& López-de-Silanes, 2007). Thus, stock prices are not more closely related to the decision-making process, especially considering the real side of the economy.

However, it cannot be inferred from this that the capital market is irrelevant to decisions on corporate investments. As noted by Bond et al. (2012), other mechanisms of information transmission may be relevant to decisions, such as those regarding compensation contracts based on the performance of stock returns. Another example of the interaction between stock prices and investments is identified in Polk and Sapienza (2009). For the authors, the levels of undervaluation and overvaluation of stocks are important factors on which managers rely when making investments.

What the results of the study showed is that there was not an effect between corporate investments and the Q ratio. Thus, there are no indications that supported Hypothesis 1. This result was robust when different levels of informational efficiency of stock prices were taken into consideration, which in turn suggests an essential distinction in LA between the informational and allocational efficiency found in the capital markets. Additionally, it was identified that in periods of greater economic strength in LA, as in the commodities cycle, the Q ratio did not include a relevant driver for investments.

In contrast, the evidence obtained indicates that the internal generation of resources (cash flows) represents one of the main drivers of corporate investments in the BCMP countries, which supports Hypothesis 2. This result is in line with the studies of Larkin et al. al. (2017) and Moshirian et al. (2017) for the case of underdeveloped and emerging countries.

However, there was no evidence that the relationship between investments and cash flow lost relevance during the period analyzed (2000 to 2017). Nor has it been found that a more significant relationship between investments and cash flow translates into a greater restriction of firms in attracting external resources.

In a region where economic agents are cautious about making long-term investments, even with more promising expectations (Leite et al., 2018), the relationship between investments and cash flow for the BCMP countries indicates an effect due to market imperfections (informational asymmetries and agency conflicts) and to the uncertainties associated with the generation of future cash flows. An example of this can be seen in Artica et al. (2019) and Agca and Mozumdar (2008).

Other factors such as sales levels and asset tangibility have been associated with corporate investments while credit ratings and ADR programs have not demonstrated such an association. For the variable that measures the levels of property rights (Rule_Law), no significant results were found. The variable Rule_law presented low values in comparison to the values verified in developed economies, as noted by Chong and López-de-Silanes (2007).

There is evidence that the periods of greater financial market turmoil in LA (financial crisis) are negatively associated with corporate investments. This evidence suggests a mechanism for the transmission of information between the financial markets without necessarily a higher economic approximation among the BCMP countries.

\section{Conclusions}

Decisions on corporate investments are one of the most critical topics for finance. Understanding its determinants to a certain extent means identifying processes of growth and stagnation of firms and sectors and within a broader perspective, the levels of development achieved by countries and regions globally. With the emergence of new technologies related to the areas of information technology, industrial automation, and artificial intelligence, this challenge is becoming increasingly evident.

For LA, the literature on the drivers of investments is relatively scarce and remains quite inconclusive. Thus, the present study aimed to identify these drivers of value. The results pointed to a positive association between the internal generation of resources (cash flow) and corporate investment. In contrast, there were no indications that stock prices transmit information relevant to corporate investment decisions in the region of BCMP countries.

However, the results obtained should be viewed with caution when generalized to other countries or regions. According to Leite et al. (2018), LA has certain idiosyncrasies that differentiate it in several respects from different locations with the same profile of economic and social development.

For future research, it would be interesting to advance the question of how peer firms' information impacts 
corporate investments. This type of investigation can be observed in Park, Yang, and Yang (2017) and Mama (2017). Other relevant issues relatel to the payment of dividends (Adhikari \& Agrawal, 2018), earnings management (Du \& Shen, 2018), and cost of capital (Shroff, Verdi, \& Yost, 2017), among others. All these questions are very nascent in the LA context.

\section{References}

Abel, A. B. (2018). The effects of q and cash flow on investment in the presence of measurement error. Journal of Financial Economics, 128(2), 363-377. https://doi.org/10.1016/j.jfineco.2018.02.005

Adhikari, B. K., \& Agrawal, A. (2018). Peer influence on payout policies. Journal of Corporate Finance, 48, 615-637. https://doi.org/10.1016/j.jcorpfin.2017.12.010

Agca, S., \& Mozumdar, A. (2008). The impact of capital market imperfections on investment-cash flow sensitivity. Journal of Banking and Finance, 32(2), 207-216. https://doi.org/10.1016/j.jbankfin.2007.02.013

Agca, S., \& Mozumdar, A. (2017). Investment-cash flow sensitivity: fact or fiction? Journal of Financial and Quantitative Analysis, 52(3), 1111-1141. https://doi.org/10.1017/S0022109017000230

Aguilera, R. V., Ciravegna, L., Cuervo-Cazurra, A., \& Gonzalez-Perez, M. A. (2017). Multilatinas and the internationalization of Latin American firms. Journal of World Business, 52(4), 447-460. https://doi.org/10.1016/j.jwb.2017.05.006

Allayannis, G., \& Mozumdar, A. (2004). The impact of negative cash flow and influential observations on investment-cash flow sensitivity estimates. Journal of Banking and Finance, 28(5), 901-930. https://doi.org/10.1016/S0378-4266(03)00114-6

Arellano, M., \& Bond, S. (1991). Some tests of specification for panel data: Monte Carlo evidence and an application to employment equations. Review of Economic Studies, 58(2), 277-297. https://doi.org/10.2307/2297968

Artica, R. P., Brufman, L., \& Saguí, N. (2019). Por que as empresas latino-americanas retêm muito mais caixa do que costumavam reter? Revista Contabilidade \& Finanças, 30(79), 73-90. http://dx.doi.org/10.1590/1808-057x201805660

Ascioglu, A., Hegde, S. P., \& McDermott, J. B. (2008). Information asymmetry and investment-cash flow sensitivity. Journal of Banking and Finance, 32(6), 1036-1048. https://doi.org/10.1016/j.jbankfin.2007.09.018

Bekaert, G., Harvey, C. R., \& Lundblad, C. (2007). Liquidity and expected returns: lessons from emerging markets. The Review of Financial Studies, 20(5), 1783-1831. https://doi.org/10.1093/rfs/hhm030

Bittencourt, M. (2012). Financial development and economic growth in Latin America: is Schumpeter right? Journal of Policy Modeling, 34(3), 341-355. https://doi.org/10.1016/j.jpolmod.2012.01.012

Blanchard, O., Rhee, C., \& Summers, L. (1993). The stock market, profit, and investment. The Quartely Journal of Economics, 108(1), 115-136. https://doi.org/10.2307/2118497

Bond, P., Edmans, A., \& Goldstein, I. (2012). The real effects of financial markets. Annual Review of Financial Economics, 4, 339-360. Retrieved from https://doi.org/10.1146/annurev-financial-110311-101826

Braun, M., Briones, I., \& Islas, G. (2019). Interlocking directorates, access to credit, and business performance in Chile during early industrialization. Journal of Business Research, 105, 381-388. https://doi.org/10.1016/j.jbusres.2017.12.052

Brenes, E. R., Camacho, A. R., Ciravegna, L., \& Pichardo, C. A. (2016). Strategy and innovation in emerging economies after the end of the commodity boom: insights from Latin America. Journal of Business Research, 69(10), 4363-4367. https://doi.org/10.1016/j.jbusres.2016.03.059

Campello, M., \& Chen, L. (2010). Are financial constraints priced? Evidence from firm fundamentals and stock returns. Journal of Money, Credit and Banking, 42(6), 1185-1198. https://doi.org/10.1111/j.1538-4616.2010.00326.x

Chan, K., \& Hameed, A. (2006). Stock price synchronicity and analyst coverage in emerging markets. Journal of Financial Economics, 80(1), 115-147. https://doi.org/10.1016/j.jfineco.2005.03.010

Chen, H., \& Chen, S. (2012). Investment-cash flow sensitivity cannot be a good measure of financial constraints: evidence from the time series. Journal of Financial Economics, 103(2), 393-410. https://doi.org/10.1016/j.jfineco.2011.08.009 
Chen, Q., Goldstein, I., \& Jiang, W. (2007). Price informativeness and investment sensitivity to stock price. The Review of Financial Studies, 20(3), 619-650. https://doi.org/10.1093/rfs/hhl024

Chong, A., \& López-de-Silanes, F. (2007). Investor protection and corporate governance: firm-level evidence across Latin America. Latin American Development Forum. Retrieved from https://www.ssrn.com/abstract=1820067.

Chowdhury, J., Kumar, R., \& Shome, D. (2016). Investment cash-flow sensitivity under changing information asymmetry. Journal of Banking and Finance, 62, 28-40. https://doi.org/10.1016/j.jbankfin.2015.07.003

Cleary, S. (1999). The relationship between firm investment and financial status. The Journal of Finance, 54(2), 673-692. https://doi.org/10.1111/0022-1082.00121

Cuervo-Cazurra, A., Ciravegna, L., Melgarejo, M., \& Lopez, L. (2018). Home country uncertainty and the internationalization-performance relationship: building an uncertainty management capability. Journal of World Business, 53(2), 209-221. https://doi.org/10.1016/j.jwb.2017.11.002

Damodaran, A. (2001). Corporate Finance (2nd ed.). New York, NY: John Wiley.

Diao, X., Mcmillan, M., \& Rodrik, D. (2017). The recent growth boom in developing economies: a structural-change perspective. [Working Paper No 23132]. The National Bureau of Economic Research, Cambridge, MA.

Donadelli, M., \& Persha, L. (2014). Understanding emerging market premia: industries, governance and macroeconomic policy uncertainty. Research in International Business and Finance, 30, 284-309. https://doi.org/10.1016/j.ribaf.2013.09.008

Du, Q., \& Shen, R. (2018). Peer performance and earnings management. Journal of Banking and Finance, 89, 125-137. https://doi.org/10.1016/j.jbankfin.2018.01.017

Erickson, T., \& Whited, T. M. (2000). Measurement error and the relationship between investment and q. Journal of Political Economy, 108(5), 1027-1057. http://dx.doi.org/10.2139/ssrn.284428

Erickson, T., \& Whited, T. M. (2002). Two-step GMM estimation of the errors-in-variables model using high-order moments. Econometric Theory, 18(3), 776-799. https:// 10.1017/S0266466602183101

Erickson, T., \& Whited, T. M. (2012). Treating measurement error in Tobin's q. Review of Financial Studies, 25(4), 1286-1329. https://doi.org/10.1093/rfs/hhr120

Escobari, D., Garcia, S., \& Mellado, C. (2017). Identifying bubbles in Latin equity markets: phillips-perron-based tests and linkages. Emerging Markets Review, 33, 90-101. https://doi.org/10.1016/j.ememar.2017.09.001

Fama, E. F., \& French, K. R. (2017). International tests of a five-factor asset pricing model. Journal of Financial Economics, 123(3), 441-463. https://doi.org/10.1016/j.jfineco.2016.11.004

Fama, E. F., \& French, K. R. (2018). Choosing factors. Journal of Financial Economics, 128(2), 234-252. https://doi.org/10.1016/j.jfineco.2018.02.012

Fazzari, S. M., Hubbard, R. G., \& Petersen, B. C. (1988). Financial constraints and corporate investment. Brookings Papers on Economic Activity, 141-195. https://doi.org/ 10.2307/2534426

Fernandez, V. (2017). The finance of innovation in Latin America. International Review of Financial Analysis, 53, 37-47. https://doi.org/10.1016/j.irfa.2017.08.008

Figlioli, B., \& Lima, F. G. (2019). Stock pricing in Latin America: the synchronicity effect. Emerging Markets Review, 39, 1-17. https://doi.org/10.1016/j.ememar.2019.03.002

Foucault, T., \& Frésard, L. (2012). Cross-listing, investment sensitivity to stock price, and the learning hypothesis. The Review of Financial Studies, 25(11), 3305-3350. https://doi.org/10.1093/rfs/hhs093

Gonzalez, M., Molina, C. A., Pablo, E., \& Rosso, J. W. (2017). The effect of ownership concentration and composition on dividends: evidence from Latin America. Emerging Markets Review, 30, 1-18. https://doi.org/10.1016/j.ememar.2016.08.018

Grandes, M., Panigo, D. T., \& Pasquini, R. A. (2010). On the estimation of the cost of equity in Latin America. Emerging Markets Review, 11, 373-389. https://doi.org/10.1016/j.ememar.2010.08.001

Grullon, G., Hund, J., \& Weston, J. P. (2018). Concentrating on q and cash flow. Journal of Financial Intermediation, 33, 1-15. https://doi.org/10.1016/j.jfi.2017.10.001 
Hayashi, F. (1982). Tobin's marginal q and average q: a neoclassical interpretation. Econometrica, 50(1), 213-224. https://doi.org/10.2307/1912538

Hou, K., \& Moskowitz, T. J. (2005). Market frictions, price delay, and the cross-section of expected returns. Review of Financial Studies, 18(3), 981-1020. https://doi.org/10.1093/rfs/hhi023

Jensen, M. C. (1986). Agency costs of free cash flow, corporate finance, and takeovers. The American Economic Review, 76(2), 323-329.

Jensen, M. C., \& Meckling, W. H. (1976). Theory of the firm: managerial behavior, agency costs and ownership structure. Journal of Financial Economics, 3(4), 305-360. https://doi.org/10.1016/0304-405X(76)90026-X

Kadapakkam, P., Kumar, P., \& Riddick, L. (1998). The impact of cash flows and firm size on investment: the international evidence. Journal of Banking and Finance, 22(3), 293-320. https://doi.org/10.1016/S0378-4266(97)00059-9

Kaplan, S. N., \& Zingales, L. (1997). Do investment-cash flow sensitivities provide useful measures of financing constraints? The Quartely Journal of Economics, 112(1), 169-215. https://doi.org/10.1162/003355397555163

Larkin, Y., Ng, L., \& Zhu, J. (2018). The fading of investment-cash flow sensitivity and global development. Journal of Corporate Finance, 50, 294-322. https://doi.org/10.1016/j.jcorpfin.2018.04.003

Leite, A. L., Klotzle, M. C., Pinto, A. C. F., \& Silva, A. F. (2018). Size, value, profitability, and investment: evidence from emerging markets. Emerging Markets Review, 36, 45-59. https://doi.org/10.1016/j.ememar.2018.04.006

Lewellen, J., \& Lewellen, K. (2016). Investment and cash flow: new evidence. Journal of Financial and Quantitative Analysis, 51(4), 1135-1164. https://doi.org/10.1017/S002210901600065X

Mama, H. B. (2017). The interaction between stock prices and corporate investment: is Europe different? Review of Managerial Science, 11(2), 315-351. https://doi.org/10.1007/s11846-015-0187-3

Manuelito, S., \& Jiménez, L. F. (2015). Stylized features of the investment-growth connection in Latin America, 1980-2012. Cepal Review, 115, 7-22. https://doi.org/10.18356/2284cf80-en

Mensi, W., Hammoudeh, S., Reboredo, J. C., \& Nguyen, D. K. (2014). Do global factors impact BRICS stock markets? A quantile regression approach. Emerging Markets Review, 19, 1-17. https://doi.org/10.1016/j.ememar.2014.04.002

Modigliani, F., \& Miller, M. (1958). The cost of capital, corporation finance, and the theory of investment. American Economic Review, 48(3), 261-297.

Morck, R., Shleifer, A., \& Vishny, R. W. (1990). The stock market and investment: is the market a sideshow? Brookings Papers on Economic Activity, 2, 157-215. https://doi.org/ 10.2307/2534506

Morck, R., Yeung, B., \& Yu, W. (2000). The information content of stock markets: why do emerging markets have synchronous stock price movements? Journal of Financial Economics, 58(1-2), 215-260. https://doi.org/ 10.1.1.197.5418

Moshirian, F., Nanda, V., Vadilyev, A., \& Zhang, B. (2017). What drives investment-cash flow sensitivity around the world? An asset tangibility perspective. Journal of Banking and Finance, 77, 1-17. https://doi.org/10.1016/j.jbankfin.2016.12.012

Myers, S. C., \& Majluf, N. S. (1984). Corporate financing and investment decisions when firms have information that investors do not have. Journal of Financial Economics, 13, 187-221. https://doi.org/10.1016/0304-405X(84)90023-0

Park, K., Yang, I., \& Yang, T. (2017). The peer-firm effect on firm's investment decisions. North American Journal of Economics and Finance, 40, 178-199. https://doi.org/10.1016/j.najef.2017.03.001

Piotroski, J. D., \& Roulstone, D. (2004). The influence of analysts, institutional investors, and insiders on the incorporation of market, industry, and firm-specific information stock prices. The Accounting Review, 79(4), 1119-1151. https://doi.org/10.2308/accr.2004.79.4.1119

Polk, C., \& Sapienza, P. (2009). The stock market and corporate investment: a test of catering theory. The Review of Financial Studies, 22(1), 187-217. https://doi.org/10.1093/rfs/hhn030

Roggi, O., Giannozzi, A., \& Baglioni, T. (2017). Valuing emerging markets companies: new approaches to determine the effective exposure to country risk. Research in International Business and Finance, 39, 553-567. https://doi.org/10.1016/j.ribaf.2016.07.028 
Rosseau, P. L., \& Kim, J. H. (2008). A flight to Q? Firm investment and financing in Korea before and after the 1997 financial crisis. Journal of Banking and Finance, 32(7), 1416-1429. https://doi.org/10.1016/j.jbankfin.2007.11.013

Sensoy, A. (2016). Impact of sovereign rating changes on stock market co-movements: the case of Latin America. Applied Economics, 48(28), 2600-2610. https://doi.org/ 10.1080/00036846.2015.1125437

Shroff, N., Verdi, R. S., \& Yost, B. P. (2017). When does the peer information matter? Journal of Accounting and Economics, 64(2-3), 183-214. https://doi.org/10.1016/j.jacceco.2017.03.005

Tobin, J. (1969). A general equilibrium approach to monetary theory. Journal of Money, Credit and Banking, 1(1), 15-29. https://doi.org/ 10.2307/1991374

Vianna, A. C., \& Mollick, A. V. (2018). Institutions: key variable for economic development in Latin America. Journal of Economics and Business, 96, 42-58. https://doi.org/10.1016/j.jeconbus.2017.12.002

\section{Notes}

Note 1. Markets with very high liquidity, the absence of transaction costs and taxes. It also assumes that economic agents hold all relevant information and are rational in their decisions.

Note 2. Tobin's Q is related to a marginal concept, that is, the relation between the value of an additional unit of installed capital and its respective market value. However, Hayashi (1982) shows that in some conditions the marginal $\mathrm{Q}$ and the average $\mathrm{Q}$ are equivalent.

Note 3. External funds refer to both equity and debt.

Note 4. Peru was included in the sample due to the high rate of economic growth verified in recent decades. Additional information can be obtained from the "The Global Competitiveness Report" available at: http://www3.weforum.org/docs/GCR2018/05FullReport/TheGlobalCompetitivenessReport2018.pdf.

Note 5. For the cash flow, the results were controlled in three distinct dimensions: i) cash flows staggered by total assets, ii) dispersion of cash flow, and iii) periods in which cash flows presented negative values.

Note 6. The period of the Asian Crisis is between 1997 and 1998.

Note 7. With highly contrasting results.

Note 8. The stock liquidity levels were identified through daily data (section 3.1). Monthly and annual data were used in the tests of econometric modeling (section 3.2).

Note 9. When a particular company trades more than one stock type, information was considered only for the stock with the highest level of liquidity.

Note 10. Unreported results indicate that the winsorization of the variables does not change the results in comparison with the trimming procedure.

Note 11. Model 1 is a dynamic panel-data model.

Note 12. The following stock indices were used as representative of the market portfolio: Brazil (Ibovespa), Chile (IPSA), Mexico (IPC), and Peru (S\&P/BVL Peru General).

Note 13. $\mathrm{Q}$ refers to the $\mathrm{Q}$ ratio measured from two variables: $\mathrm{Q} 1$ and $\mathrm{Q} 2$. The interactions established between the variables $\left(\mathrm{Q}, \psi_{-}\right.$it, analystsit, and sizeit) follow the econometric modeling proposed in section 3.2.1.

Note 14 . The variables directly or indirectly related to the capital structure, CF1, and CF2 (internal resource generation) and Leverageit, presented coefficients that were statistically significant as it relates to corporate investments.

Note 15. The results for the Cashit variable in models 8 and 10 should be viewed with caution because the dependent variable Total_Investit contemplates the variation of working capital in its formulation. 
Appendix A. Theoretical background of the variables used in the base models

\begin{tabular}{|c|c|}
\hline Variables & Definitions \\
\hline CAPEX $_{\text {it }}$, & Variables widely used in the investigation of the drivers of corporate investments. These \\
\hline Total_Invest ${ }_{\mathrm{it}}$, & variables are based on the work of Grullon et al. (2018), Larkin et al. (2018), Chen and \\
\hline $\begin{array}{r}\mathrm{CF} 1, \mathrm{Q} 1, \text { Sales }_{\mathrm{it}}, \\
\text { and Leverage } \\
\text { it }\end{array}$ & Chen (2012) and Agca and Mozumdar (2008). \\
\hline Q2, and CF2 & Variables based on company valuation measures, as proposed by Damodaran (2001). \\
\hline Cash $_{\text {it }}$ & $\begin{array}{l}\text { The level of cash and cash equivalents represents a kind of liquidity security mechanism } \\
\text { in LA, due mainly to the uncertainties associated with the generation of cash flows by } \\
\text { firms (Artica et al., 2019). }\end{array}$ \\
\hline $\mathrm{Ln} \_M V_{\text {it }}$ & $\begin{array}{l}\text { The size of firms is an explanatory factor between investment-Q ratio and } \\
\text { investment-cash flow (Kadapakkam et al., 1998). }\end{array}$ \\
\hline Tangibility $_{\mathrm{i}}$ & $\begin{array}{l}\text { Moshirian et al. (2017) suggest that the level of tangibility of assets is a relevant driver } \\
\text { for corporate investments. }\end{array}$ \\
\hline $\mathrm{ADR}_{\mathrm{it}}$ & $\begin{array}{l}\text { Foucault and Frésard (2012) indicate that ADR programs make stock prices more } \\
\text { informative to corporate investments. }\end{array}$ \\
\hline Rating $_{\text {it }}$ & $\begin{array}{l}\text { Credit ratings may indicate the level of firms' constraints on obtaining external resources } \\
\text { (Campello \& Chen, 2010). }\end{array}$ \\
\hline \multirow[t]{2}{*}{$\begin{array}{l}\text { Neg_CF } F_{\text {it }} \text {, and } \\
\text { Dispersion_CF } \text { it }_{\text {it }}\end{array}$} & $\begin{array}{l}\text { Variables that capture different characteristics of the cash flow (periods in which the cash } \\
\text { flow presented negative value and the dispersion of the cash flow). These variables were } \\
\text { based on Allayannis and Mozumdar (2004). }\end{array}$ \\
\hline & $\begin{array}{l}\text { Mensi, Hammoudeh, Reboredo and Nguyen (2014) note that the subprime financial crisis } \\
\text { in North America has influenced the performance of debt securities and stocks of } \\
\text { companies located in underdeveloped or emerging countries. Figlioli and Lima (2019) } \\
\text { have identified that the subprime financial crisis has impacted the process of stock pricing } \\
\text { in the LA context. }\end{array}$ \\
\hline Rule_Law & $\begin{array}{l}\text { The low levels of property rights found in undeveloped and emerging markets represent a } \\
\text { significant restriction on corporate investment (Gonzalez et al., 2007; Chong \& } \\
\text { López-de-Silanes, 2007). }\end{array}$ \\
\hline
\end{tabular}

\section{Copyrights}

Copyright for this article is retained by the author(s), with first publication rights granted to the journal.

This is an open-access article distributed under the terms and conditions of the Creative Commons Attribution license (http://creativecommons.org/licenses/by/4.0/). 